11. Greenlee, R.T. Cancer statistics, 2001 / R.T. Greenlee, M.B. HillHarmon, T. Murray, M. Thun // Cancer J. Clin. - 2001. - Vol. 51, N 15. - P. 36.

12. Katsinelos, P. Recurrent cholangitis as the first manifestation of an intraductal papillary mucinous tumor of the pancreas / P. Katsinelos, G. Paroutoglou, A. Beltsis et al. // Rom J Gastroenterol. - 2005. - Vol. 14. - P. 169-172.

\title{
Конищева А.Н. \\ Специфика организации познавательной деятельности иностранных студентов на этапе предвузовской подготовки
}

Белгородский государственный национальный исследовательский университет (Россия, Белгород) doi:10.18411/lj2016-4-10

Обучение русскому языку как иностранному рассматривается как основная часть предвузовской подготовки иностранных студентов, целью которой является формирование и развитие коммуникативной компетенции, позволяющей осуществлять коммуникацию как в ситуациях повседневного общения, так и в сфере профессиональных интересов. Специфика этапа предвузовской подготовки иностранных студентов проявляется, прежде всего, в его интенсивности, обусловленной необходимостью овладения основами русского языка в сжатые сроки, а также в необходимости обучать специалистов-нефилологов на изучаемом языке в соответствии с их потребностями для успешного осушествления дальнейшей образовательной деятельности.

В небольших учебных группах при краткосрочном обучении наиболее результативно применение интенсивных методов обучения, которые направлены на усвоение максимального объема материала в минимальные сроки. Отличительными особенностями интенсивных методов являются: 1) максимальная активизация обучающихся в ходе занятий (с этой целью предлагаются специальные задания в форме этюдов, ролевые игры, аудиовизуальные и компьютерные средства обучения); 2) мобилизация скрытых психологических резервов личности обучающихся; 3) использование всех средств воздействия на обучающихся. С помощью интенсивных методов обучения удается за сравнительно короткий отрезок времени сформировать и активизировать навыки и умения практического владения языком в пределах ограниченного набора тем и ситуаций, представляющих повышенный интерес для обучающихся. Тем самым в ходе интенсивного обучения максимально учитывается мотивационная сторона обучения. Мотивация на уроке обеспечивается, прежде всего, осознанием обучающимися успешности изучения иностранного языка, ощущением прогресса в обучении. Среди интенсивных методов обучения наиболее популярным является суггестопедический метод обучения (Г. Лозанов), который представляет собой систему введения и закрепления речевого материала в ситуациях общения, имитирующих естественную речевую среду, а также активизацию обучающихся в ходе учебного процесса и мобилизацию их скрытых психологических резервов [5, с. 52].

Результативность такого метода обучения русскому языку во многом зависит от интенсивности познавательной деятельности иностранных студентов как на занятиях в аудитории, так и во время внеаудиторной работы. Познавательная активность студентов невозможна без определенного уровня развития психических познавательных процессов, прежде всего мышления, поскольку осуществление рефлексии, самоконтроля и самооценки предполагает сформированность операций мыслительной деятельности: анализа, синтеза, сравнения, обобщения и т. д. [6, с. 163].

По мнению Л.С. Выготского только правильно организованное обучение влечет за собой умственное развитие, способствует формированию продуктивного (творческого, теоретического) мышления, познавательной активности личности [2].

В связи с этим становится актуальным применение различных форм организации познавательной деятельности обучаемых, способствующих раскрытию резервных возможностей личности, которые бы позволили иностранным студентам повысить эффективность учебно-познавательного процесса.

Под формой организации познавательной деятельности следует понимать «...целенаправленно формируемый характер общения в процессе 
взаимодействия учителя и учащихся, отличающихся спецификой распределения учебно-познавательных функций, последовательностью и выбором звеньев учебной работы и режимом - временным и пространственным» [3, с. 223].

Урок русского языка как иностранного имеет ряд особенностей, которые определяют специфику организации познавательной деятельности иностранных студентов на уроке. Обучение проходит в атмосфере общения, где его участники выступают речевыми партнерами. Русская речь является целью и средством обучения. На уроке проводится работа над разными аспектами языка (фонетикой, грамматикой, лексикой) и над развитием умений в различных видах речевой деятельности (аудированием, чтением, говорением, письменной речью). Урок проводится на русском языке, и речь преподавателя в общей сложности не должна превышать $10 \%$ времени урока. Новизна как компонент методического содержания урока русского языка как иностранного является одним из главных факторов, обеспечивающих интерес обучающихся. Здесь имеется в виду новизна содержания учебных материалов, новизна формы урока (урок - экскурсия, урок - пресс-конференция), новизна видов работы, иначе говоря, постоянная (в разумных пределах) новизна всех элементов учебного процесса. Особенность урока русского языка заключается еще и в том, что он не является самостоятельной единицей учебного процесса. Каждый урок - это звено, часть в цикле уроков, связанных между собой и обусловливающих друг друга. Уроки, как правило, объединяются в циклы в соответствии с определенной темой $[4, c .5]$.

Исходя из этого, на уроке русского языка как иностранного целесообразно объединение фронтальной, коллективной и индивидуальной форм работы. Смена форм познавательной деятельности, разнообразие средств обучения позволяют поддерживать высокий темп работы на уроке.

Одновременную работу со всей группой подразумевает фронтальная работа студентов. На занятиях организуются дискуссии по темам, интересующим и волнующим всех студентов. Это позволяет устанавливать доверительные отношения с группой, оказывать прямое, непосредственное идейно-эмоциональное воздействие на студентов, пробуждающее у них ответные мысли, чувства, переживания. Участвуя в общей работе, студент ощущает ритм совместного поиска, разделяет успех общих достижений, проявляет определенную творческую активность.

Наряду с фронтальным изложением нового материала, преподаватель широко использует фронтальную беседу, ставит проблемные и наводящие вопросы, комментирует материал и оценочными суждениями направляет ход беседы таким образом, чтобы привлекать к участию в коллективном обсуждении отдельных обучающихся с учетом их индивидуальных особенностей. Фронтальная учебная работа может быть организована и таким образом, что каждый студент выполняет задание или упражнение самостоятельно, одновременно с другими, по указанию и под руководством преподавателя. Такая индивидуальная форма особенно удачно используется во время самостоятельного выполнения письменных упражнений, работы с текстом, учебником, словарями, энциклопедиями. Педагогическая ценность этой формы организации познавательной деятельности заключается в том, что она может хорошо учитывать особенности каждого студента сообразно его подготовке и возможностям. При отборе учебных текстов учитываются пол, возраст, интересы и профессиональная направленность членов группы, накануне чтения или прослушивания текста обязательно дается притекстовое задание, требующее найти в тексте ответ на вопрос или на ряд вопросов. Созданию благоприятной психологической атмосферы на занятии и преодолению лексико-грамматических трудностей русского языка способствует обращение к стихотворной речи. Как указывала И. В. Попадейкина, работа с поэтическими текстами на уроках русского языка как иностранного является необходимой: «с одной стороны, учащиеся знакомятся с разнообразием лексического и грамматического материала, с другой стороны, активизируется их познавательная деятельность и расширяются культурологические знания» [7, с. 144].

Благоприятно сказывается на результатах обучения коллективная форма познавательной деятельности. Для развития устной речи используются учебные ситуации общения. Под учебной ситуацией понимается специально созданные условия, обстоятельства, система взаимоотношений собеседников в целях учебновоспитательного воздействия на учащихся при осуществлении речевых действий на 
иностранном языке. Учебная ситуация адекватна реальной ситуации общения и предельно ясна студентам. Это значит: четко определена задача (о чем спросить, что узнать у собеседника, о чем рассказать, что нужно доказать, уточнить, опровергнуть и т. п.). Обучающиеся знают то, что от них требуется, что они могут сделать, так как выполнение задания обеспечено конкретным языковым (слова, словосочетания, структуры) и речевым (готовые речевые клише) материалом, усваиваемым или усвоенным.

Наряду с фронтальной организацией работы иностранных студентов на занятиях применяется и такая коллективная форма, как групповая работа обучающихся, при которой возникает ситуация коллективного взаимодействия всех членов группы. При составлении диалогов, рассказов по заданной теме, озвучивании видеосюжета деятельность каждого студента становится общественно полезной, и каждый отвечает не только за свои знания, но также и за знания своих товарищей по учебной работе.

Повышению интереса иностранных студентов к изучению русского языка, способствует внеаудиторная познавательная деятельность. Познавательные экскурсии во время внеаудиторных занятий, предполагающие беседы с обучающимися накануне и после экскурсий, укрепляют их положительную мотивацию в обучении. Посещение фестивалей, выставок национальных культур демонстрируют уважительное отношение к различным традициям, обычаям, религиозным убеждениям акцентируют внимания на лучших качествах представителей каждой нации или народности.

Для развития учебно-познавательной активности иностранных студентов используются разнообразные формы самостоятельной работы. Основной задачей самостоятельной познавательной деятельности при изучении русского языка как иностранного является выбор рациональных способов творческого освоения иноязычной информации, решения поставленных учебных задач, приобретение речевых иноязычных навыков и умений $[1$, с. 16]. Высокий уровень познавательной активности и самостоятельности студентов проявляется в ходе выполнения ими творческой работы. Подготовка презентации, сообщения, составление тематических кроссвордов способствуют углублению знаний по русскому языку, закреплению изученного материала.

Познавательная деятельность иностранных студентов основывается на таких качествах личности, как самостоятельность, способность принимать ответственные решения, творческий подход к любому делу, умение постоянно учиться, коммуникабельность, способность к сотрудничеству, умение выстраивать межличностные отношения. Непосредственно в процессе познавательной деятельности происходит формирование коммуникативной компетенций. Таким образом, становится очевидным высокая важность познавательной деятельности студентов и необходимость ее эффективной организации и управления.

\section{Список используемых источников информации}

1. Архипов В. И. Развитие познавательной самостоятельности студентов в процессе усвоения учебных грамматических понятий [Текст]: автореф. дис. на соиск. уч. степ. канд. пед. наук (13.00.01) / Архипов Владимир Иванович; Татар. гос. гуманитар. пед. ун-т. - Казань, 2007 - 23 с.

2. Выготский Л.С. Педагогическая психология / Под ред. В.В.Давыдова. - М.: Педагогика, 1991. 480c.

3. Дидактика средней школы: некоторые проблемы современной дидактики / под ред. М.Н. Скаткина. - М.: Просвещение, 1982. - 319с.

4. Золотых Л. Г. Методика преподавания русского языка как иностранного в китайской аудитории : учебное пособие / Л. Г. Золотых [и др.]; под общ. ред. М. Л. Лаптевой. - Астрахань: Астраханский государственный университет, Издательский дом «Астраханский университет», 2012. - 91 c.

5. Лебединский С.И., Гербик Л. Ф. Методика преподавания русского языка как иностранного. Учебное пособие / С. И. Лебединский, Л. Ф. Гербик - Минск, 2011. - 309 с.

6. Огольцова Е.Г. Проблема активизации познавательной деятельности в дидактике высшей школы /Е. Г. Огольцова // Современные проблемы науки и образования. - 2009. - № 3 - С. 162-166.

7. Попадейкина И. В. Художественный текст на занятиях по русскому языку как иностранному / И. В. Попадейкина // Теория и практика преподавания русского языка как иностранного. - Вроцлав. 2012. - C. 136-144. 